\title{
PENDIDIKAN ISLAM: ANTARA PEMBENTUKAN KEPRIBADIAN DAN DORONGAN MEMENUHI KEBUTUHAN PASAR
}

\author{
Yunus \\ STMIK Eresha \\ Nurhang542@gmail.com
}

\begin{abstract}
Islamic education is basically a normative attempt to help someone or a group of learners in developing the Islamic world view. Globalization in addition to presenting a positive opportunity for luxury living, convenient, inexpensive, beautiful, and developed negative can also present opportunities, are causing anxiety, sorrow, and suffering. Globalization work for 24 hours by offering plenty of choice and personal freedom. In short these days there has been a "flood of options and opportunities", it's up to the person's ability to have it. Likewise, that Islamic education is in the atmosphere of modernization and globalization required to be able to play its role in a dynamic and productive. Its presence is expected to contribute significant and positive changes for the improvement and progress of Islamic civilization, both on theoretical and practical intellectual plains. Education system there seems to have contributed significantly in shaping Indonesian man who was strong and intelligent (intellectual, emotional, spiritual, physical) in order to answer the challenges of the times not only for glory for himself but also for the community and the nation.
\end{abstract}

Keywords: Problem, Islamic Education, Globalization

Pendidikan Islam pada dasarnya adalah upaya normatif untuk membantu seseorang atau sekelompok pelajar dalam mengembangkan pandangan dunia Islam. Globalisasi selain menghadirkan peluang positif untuk kehidupan mewah, nyaman, murah, indah, dan negatif berkembang juga dapat menghadirkan peluang, yang menyebabkan kecemasan, kesedihan, dan penderitaan. Globalisasi bekerja selama 24 jam dengan menawarkan banyak pilihan dan kebebasan pribadi. Singkatnya hari-hari ini telah ada "banjir pilihan dan peluang", itu tergantung pada kemampuan orang untuk memilikinya. Demikian juga, bahwa pendidikan Islam dalam suasana modernisasi dan globalisasi dituntut untuk dapat memainkan perannya secara dinamis dan produktif. Kehadirannya diharapkan dapat berkontribusi perubahan signifikan dan positif untuk peningkatan dan kemajuan peradaban Islam, baik pada dataran intelektual teoritis dan praktis. Sistem pendidikan di sana tampaknya telah memberikan kontribusi yang signifikan dalam membentuk manusia Indonesia yang kuat dan cerdas (intelektual, 
emosional, spiritual, fisik) untuk menjawab tantangan zaman tidak hanya untuk kemuliaan bagi dirinya sendiri tetapi juga untuk masyarakat dan bangsa.

Kata kunci: Masalah, Pendidikan Islam, Globalisasi

PEDAHULUAN
Pendidikan semestinya dijadikan
sebagai upaya untuk menjadikan
manusia lebih bermartabat dan
dijadikan sarana untukmenyadarkan
manusia akan arti penting nilai-nilai
kemanusiaan. Oleh sebab itu, menurut

Sudarwan Danim agenda utama pendidikan adalah proses memanusiakan manusia menjadi manusia.' Proses pemanusiaan tersebut dapat diupayakan melalui berbagai kegiatan pembelajaran yang dapat mendorong tumbuh kembangnya kesadaran nilai-nilai kemanusiaan, di antaranya melalui pendidikan agama. Dalam Undang-Undang No. 20 Tahun 2003 tentang Sistem Pendidikan Nasional pasal 37 ayat 1 dijelaskan bahwa sebagai agenda proses kemanusiaan dan pemanusiaan, pendidikan dapat dipandang dari 2 sisi, yaitu: pertama, sebagai proses pendewasaan peserta didik untuk hidup pada alam demokrasi dan, kedua, sebagai proses penyiapan peserta didik memasuki sektor ekonomi produktif.

Memposisikan pendidikan sebagai sarana untuk menyiapkan

\footnotetext{
Sudarwan Danim, Agenda Pembaruan Sistem Pendidikan (Yogyakarta: Pustaka Pelajar, 2003), 4
}

peserta didik memasuki wilayah ekonomi produktif merupakan hal semu, karena proses pembelajaran di sekolah tidak mendorong terbentuknya semangat dan kesadaran peserta didik tentang arti penting kemandirian dan keterampilan dalam menghadapi kehidupan nyata. Sementara itu dunia industri menuntut profil lulusan pendidikan yang mempunyai kualifikasi dan kompetensi sesuai dengan kebutuhan perusahaan. Sebagai akibatnya banyak dunia pendidikan di Indonesia yang berpikir secara pragmatis dengan mengikuti logika "kapitalisme" dan mengabaikan pentingnya membangun kesadaran yang humanis.

John Dewey dalam bukunya Democracy and Education menjelaskan bahwa tidak pada tempatnya mengaitkan tatanan perilaku kelembagaan pendidikan dengan kebutuhan pasar kerja, mengingat pendidikan bertujuan meneruskan citacita demokrasi. Menurut John Dewey, agenda utama pendidikan secara fungsional adalah membentuk komunitas-komunitas sosial ideal sebagai bagian dari proses tranformasi pendewasaan peserta didik, apapun 
bentuk dan ragam pendidikan itu dikemas.

Praksis pendidikan lslam di lembaga-lembaga pendidikan Islam termasuk di dalamnya pembelajaran PAI di madrasah saat ini dalam soroton, bahkan tidak sedikit para pakar pendidikan yang menyebut praksis pendidikan agama Islam telah gagal menjalankan perannya dalam mewujudkan masyarakat yang memiliki kepribadian Islami. Menurut Suyata, salah satu penyebab gagalnya pendidikan agama dalam menjalankan misi utamanya adalah karena pembelajaran agama terpisah dari konteksnya.

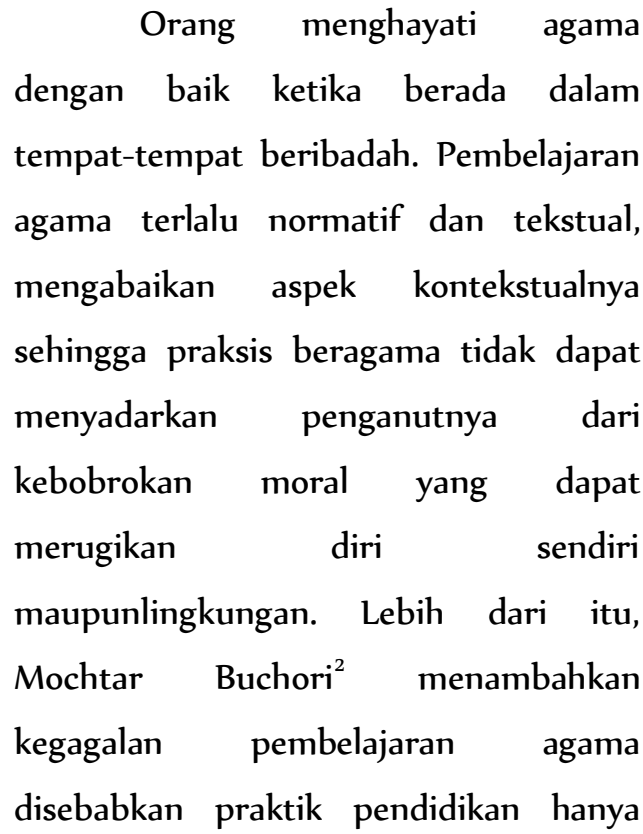

\footnotetext{
${ }^{2}$ Mochtar Buchori, "Posisi dan Fungsi Pendidikan Agama lslam dalam Kurikulum Perguruan Tinggi Umum," Makalah, pada Seminar Nasional di IKIP Malang, 24 Februari, 1992
}

memperhatikan aspek kognitif semata dari pertumbuhan kesadaran nilai-nilai agama dan mengabaikan pembinaan aspek afektifdan konatif-volitif, yakni kemauan dan tekat untuk mengamalkan nilainilai ajaran agama. Sebagai akibatnya nampak kesenjangan antara pengetahuan dan pengamalan. Fakta ini diamini oleh Menteri Agama Rl, Muhammad Maftuh Basuni bahwa pendidikan agama yang berlangsung saat ini cenderung lebih mengedepankan aspek kognitif (pemikiran) daripada afektif (rasa) dan psikomotorik (tingkah laku).

Dari berbagai sorotan yang dikemukakan para pakar Pendidikan tersebut, nampak bahwa problem pembelajaran agama terletak pada persoalan bagaimana membelajarkan agama tidak sebatas pada aspek pengetahuan tetapi juga penjiwaan dan pengamalan. Dalam konteks bagaimana membelajarkan agama lslam yang utuh, Abdurrahman Mas'ud menjelaskan bahwa pendidikan Islam pada masa lalu telahmemperlihatkan berbagai ragam transformasi budaya Islam-Jawa melalui modelling yang didemontrasikan oleh para Walisongo. ${ }^{3}$ Melalui cerita

${ }^{3}$ Abdurrahman Mas'ud, "Sejarah dan Budaya Pesantren" dalam Dinamika Pesantren dan Madrasah, (ed.) lsmail SM, et. al. (Yogyakarta: Pustaka Pelajar, 2002), 29 
pewayangan,

Walisongo

mempersonifikasikan para awliya (kekasih Allah) dan para kyai yang sarat dengan pesan-pesan moral dan kesalehan yang relevan dengan budaya lokal.

Kesederhanaan, tidak tamak, mengedepankan

kepentingan

masyarakat dan orang banyak merupakan warisan nilai-nilai luhur yang ditransformasikan oleh Walisongo dan para santrinya. Dalam sebuah rumusan naskah Islam Jawa Klasik misalnya, terdapat ungkapan “arep atatakena elmu, sakadare den lampahaken(carilah ilmu yang bisa engkau praktekkan, terapkan). ${ }^{4}$ Tentu ungkapan ini mengandung pesan bijak pentingnya belajar ilmu agama Islam yang kemudian diikuti dengan pengamalan. Konsepilmu yang operasional sudah dikenal sejak dulu dalam tradisi intelektual Islam.

Namun demikian, saat sekarang ada kesan praksis pendidikan Islam di madrasah seolah kehilangan akar sejarahnya, khususnya tradisi pesantren yang unik. Dalam tantangan global, kegigihan dalam mempertahankan prinsip-prinsip luhur serta nilai-nilai yang menjunjung tinggi harkat dan

${ }^{4}$ G.W.J. Drewes, An Early Javanese Code of Muslim Ethics (The Hague: KITL V Nijhoff Bibliotheca Indonesia, 1978), 19. martabat kemanusiaan perlu mendapatkan perhatian khusus, karena masyarakat yang gigih dan mempunyai prinsiplah yang dapat bertahan menghadapi gempuran budaya global semakin mengeyahkan nilai-nilai kemanusiaan.

Sjafri Sairin menegaskan bahwa sistem pendidikan Islam di Indonesia dari masa penjajahan sampai masa kini merupakan bagian tak terpisahkan dari sistem pendidikan nasional. ${ }^{5}$ Terjadinya dinamika perubahan dalam sistem pendidikan Islam sejak masa penjajahan hingga kini, menunjukkan indikasi yang kuat bahwa Pendidikan Islam dapat menyesuaikan diri dan beradaptasi dengan perkembangan masyarakat. Perubahan tersebut juga menggambarkan bahwa komunitas muslim dapat melakukan pembauran dalam sistem pendidikan Islam yang mereka geluti dengan dinamika yang sedang berkembang dimasyarakat saat ini.

Walaupun demikian, terdapat hal yang menarik dicermati terkait bagaimana lembaga-lembaga pendidikan Islam menghadapitantangan dan dinamika perubahan. Menurut Azyumardi Azra para eksponen

${ }^{5}$ Sjafri Sairin, Perubahan Sosial Masyarakat Indonesia: Prespektif Antropologi (Yogyakarta: Pustaka Pelajar, 2002), 35. 
Lembaga-lembaga pendidikan Islam terlihat tidak terlalu tergesa-gesa mentranformasikan perubahan kelembagaan Islam, tetapi cenderung mempertahankan kebijaksanaan yang penuh kehati-hatian, mereka menerima pembaharuan atau modernisasi secara terbatas tanpa harus melakukanperubahan sistem pendidikan Islam secara menyeluruh.Karena sesungguhnya praksis pendidikan di masing-masing Lembaga pendidikan Islam memiliki keunikan dan ciri khas, yang secara sosiologisdan filosofis tentu berbeda-beda sesuai dengan tradisi dan disiplin keilmuanyang dikembangkan para pendirinya. ${ }^{6}$

Menurut Affandi Mochtar ${ }^{7}$ pendidikan Islam Indonesia, telah menjadi

bagian penting dalam dinamika perubahan Sistem Pendidikan Nasional.

Pesantren sebagai salah satu bentuk pendidikan Islam Indonesia diasumsikan dapat menjembatani problem komunikasi antara pemerintah dengan lapisan masyarakat bawah, karenahampir sebagain besar pesantren

${ }^{6}$ Azyumardi Azra, "Pesantren: Kontinuitas dan Perubahan" dalam Nurcholish Madjid, Bilik-Bilik Pesantren: Sebuah Potret Perjalanan (Jakarta: Paramadina, 1997).

${ }^{7}$ Affandi Mochtar, Membedah Diskursus Pendidikan Islam (Ciputat: Kalimah, 2001), 77-82 di Indonesia, tumbuh dan berkembang dari lapisan bawah masyarakat. Kini sebagaian besar pesantren lebih terbuka untuk menerima arus modernisasi. Indikasi ini nampak dari adanya berbagai kegiatan yang mendorong partisipasi pesantren dalam pembangunan. Pesantren dan Lembaga pendidikan lslam yang lainnya kini sangat terbuka dengan berbagai temuan yang dihasilkan oleh pengembangan ilmu pengetahuan dan teknologi.

\section{METODOLOGI PENELITIAN}

Dalam penelitian ini igunakan pendekatan kualitatif yang menggunakan sumber primer seperti buku, artikel terkait dan hasil analisis teori ahli pada materi penelitian terkait, tujuannya ialah mennambah wawasan berdasarkan hipotesa peneliti dan menemukan teori baru

PEMBAHASAN

DAN

HASIL

PENELITIAN

Problem Esensial Madrasah Sebagai Institusi Islam Dalam Era Global

Terdapat tiga masalah mendasar yang dihadapi madrasah saat ini, $^{8}$ antara lain: pertama, masalah identitas madrasah. ${ }^{9}$ Masalah ini

\footnotetext{
${ }^{8}$ Sahal Mahfudh, Nuansa Fiqih Sosial (Yogyakarta: LKiS, 1994), 278-279

${ }^{9}$ Perlu diingat bahwa kelahiran madrasah di Indonesia merupakan bentuk modernisasi sistem pendidikan tradisional Islam yang berbentuk surau dan pesantren. Oleh sebab itu, seharusnya madrasah harus berpijak kepada nilai-nilai yang dikembangkan oleh
} 
bersumber dari respon madrasah terhadap realitas yang berkembang di masyarakat. Realitas masyarakat Indonesia saat ini, sedang dalam masa transisi sebagai dampak terjadinya proses reformasi. Persoalan demokrasi, hak asasi manusia, pluralitas, kebebasan pers dan globalisasi menjadi isu utama dalam kehidupan masyarakat Indonesia saat ini. Sementara itu, realitas yang berkembang di madrasah pada umumnya lamban dalam merespon isuisu yang berkembang di masyarakat. Kedua, masalah sumberdayamanusia internal madrasah dan pemanfaatannya bagi pengembangan madrasah ke depan.

Mayoritas sumberdaya manusia yang dimiliki madrasah homogen, lulusan perguruan tinggi Islam, kecenderungannya memiliki disiplin keilmuan yang sama. Sehingga pengembangan madrasah menjadi kurang dinamis dan inovatif. Dilihat dari struktur keilmuan yang dikembangkan di madrasah, sudah saatnya keahlian, kualifikasi dan kompetensi menjadi pertimbangan utama dalam melakukan rekrutmen tenaga pendidik di madrasah. Tentu selain beberapa pertimbangan tersebut, para guru juga harus dikenalkan dengan tradisi madrasah sebagai institusi lslam

model pendidikan tradisional lslam yang relevan, sehingga model tersebut tidak perlu ditinggalkan sepenuhnya yang dekat dengan tradisi pesantren. Sehingga nilai-nilai pesantren tidak diabaikan. Ketiga, masalah pengelolaan madrasah. Menurut H.A.R. Tilaar, persoalan madrasah terletak dari keunikannya bahwa madrasah tumbuh dari bawah, dari masyarakat sendiri. ${ }^{10}$

$$
\text { Terselenggaranya sistem }
$$
pendidikan nasional yang relevan dan bermutu merupakan faktor penentu keberhasilan bangsa Indonesia dalam mencerdaskan kehidupan bangsa dan memajukan kebudayaan nasional. Karena itu, para pendiri Republik Indonesia menetapkan upaya mencerdaskan kehiduan bangsa sebagai salah satu fungsi penyelenggaraan pemerintah negara Indonesia dan mewajibkan pemerintah menyelenggarakan satu sistem pengajaran nasional."

Dalam era globalisasi ini, sistem pendidikan nasional Indonesia dihadapkan pada sejumlah tantangan berat yang menuntut untuk dipecahkan. Persoalan-persolan tersebut antara lain: persoalan pemerataan, mutu

${ }^{10}$ Tilaar, Paradigma Baru Pendidikan Nasional, (Bandung:Rineka Cipta, 2004), 153.

"Soedijarto, Landasan dan Arah Pendidikan Nasional Kita (Jakarta: Kompas, 2008), 78-79 
pendidikan, relevansi dan efisiensi. ${ }^{12}$ Padahal secara yuridis, pemerintah menjamin pembiayaan lembaga pendidikan melalui berbagai kebijakan, antara lain: pemberian BOS (Bantuan Operasional Sekolah), dana alokasi khusus untuk peningkatan mutu pendidikan, dana yang disusun melalui RAPBS, dan lain sebagainya.

Dalam konteks ini, sebenarnya madrasah jauh memiliki peran yang lebih besar dibandingkan sekolahsekolah negeri pada umumnya. Karena hampir sebagian peserta didik yang tidak tertampung di sekolah-sekolah, pada akhirnya memilih madrasah sebagai tempat belajar. Terlepas dari persoalan adanya dugaan dan kecurigaan sebagian pihak yang mengatakan bahwa proses pendidikan di madrasah tidak bermutu dan input pendidikannya rendah, namun kesediaan madrasah untuk menerima anggota masyarakat turut dalam proses pembelajaran merupakan poin penting dalam mewujudkan gerakan education for all.

Pengembangan Institusi Pendidikan
Islam Indonesia Dalam Era Globalisasi
Globalisasi berkaitan erat
dengan modernisasi, yang dalam
perkembangannya telah melahirkan

${ }^{12}$ Suyanto, Reformasi Pendidikan Nasional (Jakarta: Komite Reformasi Pendidikan Departemen Pendidikan Nasional, 2001), 4. efek-efek positif, misalnya rasionalisasi, standarisasi dan kontrol, namun demikian modernisasi juga melahirkan efek-efek negatif, misalnya alienasi, ketidakpuasaan, ketidakstabilan atau perubahan yang terjadi secara terus menerus. Dalam sebuah artikel yang sangat populer, Samuel Huntington menjelaskan adanya Clash of civilization. Dalam sebuah paper yangkontroversial tersebut Huntington berargumen bahwa aspek terpentingdalam politik global yang akan terjadi dalam waktu dekat adalah benturanperadaban. Dengan berakhirnya perang dingin, politik internasional akanmeninggalkan fase Barat-nya, dan pusat perhatian berpindah menjadi interaksi antara peradaban Barat dan non Barat dan antar peradaban non Barat.

Suka atau tidak, kekuatan globalisasi memang telah merangsek dalamsendi-sendi kehidupan bermasyarakat, dimanapun masyarakat itu

berada,

termasuk di Indonesia. Penggunaan teknologi "kotak" (handphone, televisi,internet, dan lain sebagainya) menjadikan dunia sangat sempit. Orang dalam hitungan detik dapat melakukan perubahan atau berubahmempengaruhi orang lain, karenapengaruh teknologi komunikasi yang begitu dahsyat. Menurut Imam Barnadib dengan 
perkembangan informasi yangdisebarkan melalui penyebaran informasi yang beraneka ragam, seolah olah manusia "kebanjiran" berbagai informasi, seperti ilmu pengetahuan, iklan-iklan, baik barang maupun hiburan, maka tugas pendidikan adalahmenyiapkan peserta didik bukan sekedar sebagai "penerima" informasi tetapijuga "penyeleksi" informasi. ${ }^{13}$

Pancasila adalah ideologi dan falsafah bangsa Indonesia. Karena Pancasila sebagai ideologi dan falsafah terbuka, maka nilai-nilai yang termuat dalam filsafat selain Pancasila yang memiliki relevansi dengan semangat Pancasila dapatdiambil dan diterapkan dalam sistem pendidikan nasional Indonesia. Sebagai contoh adalah kecenderungan pendidikan di Indonesia yang berdimensi seumur hidup, semesta, menyeluruh dan terpadu.

Sementara itu kecenderunganpendidikan di dunia mempunyai isu tentang pengembangan manusia yangberbudaya, memiliki ilmu pengetahuan dan profesional. Isu ini sejalan dengan gejala universal bahwamasyarakat selalu berubah dan berkembang.

\footnotetext{
${ }^{13}$ Imam Barnadib, Filsafat Pendidikan (Yogyakarta: Adicita, 2002), 40
}

Oleh karena itu, masyarakat modern Indonesia yang sedang timbul, perlu membuat perspektif baru tentang pendidikan di Indonesia yang dapat dilandasi olehtinjauan kritis dengan menemukan kongruensi teori sumberdaya manusia,revitalisasi dan rekonstruksionisme. Sehingga pada gilirannya system pendidikan Indonesia tidak menghasilkan lulusan yang teralineasi dari system kehidupan global tetapi dapat melahirkan peserta didik yang memiliki kepribadian dan jati diri sebagai warga masyarakat Indonesia dan dapat berperan serta dalam tatanan kehidupan global.

Paradigma di atas tentu juga berlaku pada sistem pendidikan Islam sebagai bagian dari sistem pendidikan Nasional Indonesia. Krisis multidimensional yang melanda bangsa Indonesia saat ini, khususnya krisis moral dan mental menjadi poin penting dankeprihatinan bersama, terlebih ketika globalisasi menuntut adanya pembangunan karakter yang kuat. Bangsa yang lemah hanya akan menjadi sasaran empuk imperialism modern dengan berbagai produknya baik ekonomi, politik, budaya maupun ideologi.

Sistem pendidikan Islam mestinya mulai menata diri bagaimana menghadapi globalisasi yang 
menghadirkan 2 sisi negatif dan positif. Di antara upaya tersebut adalah memperbaiki kurikukulum, meningkatkan kualitas proses, memperbaiki manajemen dan mereformasi paradigma pendidikan yang berkembang saat ini dengan paradigma organik.

Di sisi lain, Kemajuan-kemajuan yang dicapai dalam ilmu dan teknologi (IPTEK) telah membantu manusia dalam mempertahankan dan atau meningkatkan taraf dan kualitas hidupnya. Berbagai kemudahan telah diperoleh umat manusia berkat kemajuan IPTEK. Namun di lain pihak, pemanfaatan kemajuan lpteks tanpa tanggung jawab moral dapat pula menyeret umat manusia ke lembah kehancuran, misalnya untuk industri tanpa kepedulian terhadap kesehatan lingkungan dan untuk perang. Dengan makin banyaknya kemungkinan untuk meraih keuntungan dari berbagai kemajuan IPTEK dan juga makin meningkatnya kekhawatiran akan terancamnya eksistensi manusia, baik secara kelompok maupun perorangan, makin banyak pula konflik kepentingan yang muncul yang pada gilirannya akan menimbulkan ketegangan-ketegangan karena Tarik ulur dari dua sisi yang berbeda. Berikut ini keteganganketegangan yang diperkirakan akan menjadi masalah utama yang perlu dipecahkan oleh warga dunia global di abad mendatang. seperti diuraikan dalam laporan UNESCO. ${ }^{14}$

1. Ketegangan antara kepentingan global dan kepentingan lokal: secara bertahap setiap insan perlu menjadi warga global tanpa kehilangan akarnya, tetapi perlu tetap aktif berperan dalam kehidupan bangsa dan masyarakat lokalnya.

2. Ketegangan antara orientasi nilai universal dan nilai perorangan: secara pelan tetapi pasti, dalam batas tertentu, budaya menjadi terglobalisasi.

Globalisasi menawarkan sederet keuntungan sekaligus mengandung resiko, termasuk resiko terabaikannya karakter unik setiap insan manusia, yang pada hakekatnya bebas memilih masa depannya sendiri dan mencapai seluruh potensinya dalam kekayaan tradisi dan lingkup budayanya sendiri yang, bila tidak dijaga, dapat terancam oleh perkembangan kontemporer.

3. Ketegangan antara tradisi dan modernitas, yang merupakan bagian dari masalah yang sama: bagaimana mungkin menyesuaikan diri dengan

${ }^{14}$ Delors et al., La Educación Encierra Un Tesoro, 1997. 
perubahan tanpa mem-belakangi masa lalu, bagaimana otonomi dapat diperoleh dengan tetap mendukung perkembangan bebas orang lain, dan bagaimana kemajuan ilmu dapat diasimilasikan? Tantangantantangan ini perlu dijawab dengan bantuan teknologi informasi yang baru.

\section{Bagaimana halnya di Indonesia?} Menurut pengamatan penulis, ketegangan-ketegangan di atas terasa telah ada di negara ini. Bahkan telah terasa adanya ketegangan lain, seperti antara kepentingan daerah dan nasional, antara kepentingan partai dan kepentingan bangsa, dan antara kepentingan individu dan kepentingan umum. Bagi bangsa yang sangat majemuk dalam berbagai aspek seperti Indonesia, ketegangan yang timbul karena keragaman kepentingan merupakan hal yang wajar, dan warganya mesti terlatih untuk menyelesaikannya. Akan tetapi pengalaman berbangsa dan bernegara di masa Orde Baru yang menekankan keseragaman tidak melatih bangsa lndonesia untuk mengatasai konflik kepentingan.

jika kita amati, bahwa peyelenggaraan pendidikan di Indonesia secara umum terdapat dua permasalahan besar yang terjadi dalam perkembangannya, antara lain; Pertama; bahwa keadaan yang sedang terjadi dalam sistem pendidikan di Indonesia saat iniadalah krisis kepemimpinan pendidikan. Kedua; secara umum penyelenggaraan program pendidikan dewasa ini menunjukan adanya peningkatan kualitas yang signifikan dalam menciptakan kualitas hidup Bangsa, khususnya dalam pembangunan manusia Indonesia yang seutuhnya, apalagi ke arah terciptanya masyarakat belajar yang melek lptek dan Imtaq serta mampu menjawab tantangan global seperti sekarang ini walaupun dalam realitasnya masih banyak kekurangan pada berbagai aspeknya. Memang pendidikan menurut hakikatnya tidak akan terlepas dari situasi yang kritis, kecuali dalam masyarakat yang masih sangat terbelakang. Hal ini disebabkan pendidikan sebagai suatu lembaga sosial cenderung mempertahankan nilai-nilai yang diemban oleh masyarakat, sementara itu proses perubahan terus berjalan dalam kehidupan sosial. Seperti yang telah kita saksikan, pembangunan nasional pada reformasi ini memang banyak mengalami perubahan yang telah dicapai, namun seiring dengan perubahan-perubahan itu, selalu muncul pula masalah-masalah baru atau krisis, baik karena kebutuhan yang meningkat 
akibat pembangunan itu sendiri, maupun karena adanya kemungkinan kekeliruan dalam membuat perencanaan. Ketiga; system penyelenggaraan pendidikan di Indonesia terjadi dikotomi antara IPTEK dan ilmu agama.

Tugas pendidikan adalah membawa generasi ini merengkuh sedemikian agar manusia tidak tercabut dari kemampuannya dalam menghadapi kontradiksi alam yang selalu mengalami perubahan. ${ }^{15}$ Globalisasi sebagai proses terkait dengan globalution, yaitu paduan dari globalization dan evolution. Dalam hal ini, globalisasi adalah hasil perubahan (evolusi) dari hubungan masyarakat yang membawa kesadaran baru tentang hubungan atau interaksi antarumat manusia. ${ }^{16}$

Namun demikian, hanya sedikit orang yang sadar dan secara kritis memahami bahaya globalisasi yang secara sistematik mengancam kehidupan manusia. Sebab globalisasi hanya dipahami dari aspek kemajuan teknologi saja bukan dari aspek-aspek lain yang

15 Mastuhu, Menata Ulang Pemikiran Sistem Pendidikan Nasional dalam Abad 21 (Yogyakarta: Safria Insani Press, 2004), h. 10.

16 Nurani Soyomukti, Pendidikan Berperspektif Globalisasi (Yogyakarta: Ar-Ruzz Media, 2008), h. 43 sesungguhnya mempunyai implikasi sosial luar biasa dalam kehidupan manusia. Bila entitas tadi telah menjadi lifestyle dan simbol kemodernan, ia dapat mengubah kebiasaan hidup seseorang, bahkan tak jarang menilai ajaran agama sebagai ketinggalan zaman. $^{17}$

Isu globalisasi bukanlah wacana baru dalam lingkungan masyarakat, dan barang kali kita memang tidak dapat lepas dari jeratan sistem yang dibentuk olehnya. Globalisasi bisa menjelma menjadi peluang, begitu pula tantanganbagi pendidikan lslam. Posisi pendidikan lslam yang perlu dipertahankanadalah sikapnya yang telah selektif, kritis dan terbuka terhadapmunculnya turbulensi arus global, bukan dengan sikap eksklusif, atauterseret arus global sehingga mengikis identitas pendidikan Islam itu sendiri. Menutup diri atau membuka kran bagi hadirnya arus global, keduanya tetaplah mengandung konsekuensi.

\section{Dampak Era Globalisasi Terhadap Pendidikan Islam}

Kehadiran globalisasi tentunya membawa pengaruh bagi kehidupan suatu negara termasuk Indonesia.

17 Musthafa Rembangy, Pendidikan Transformatif (Yogyakarta: Teras, 2008), 1 
Pengaruh globalisasi di berbagai bidang kehidupan seperti kehidupan politik, ekonomi, ideologi, sosial budaya yang akan mempengaruhi nilai-nilai nasionalisme terhadap bangsa. Ada beberapa pengaruh positif globalisasi terhadap nilai-nilai nasionalisme: pertama, dilihat dari sisi globalisasi politik, pemerintahan dijalankan secara terbuka dan demokratis. Karena pemerintahan adalah bagian dari suatu negara, jika pemerintahan dijalankan secara jujur, bersih dan dinamis tentunya akan mendapat tanggapan positif dari rakyat.

Tanggapan positif tersebut berupa rasa nasionalisme terhadap negara menjadi meningkat. Kedua, dari aspek globalisasi ekonomi, terbukanya pasar internasional, meningkatkan kesempatan kerja dan meningkatkan devisa negara. Dengan adanya hal tersebut akan meningkatkan kehidupan ekonomi yang menunjang kehidupan nasional bangsa. Ketiga, dari globalisasi sosial budaya kita dapat meniru pola berpikir yang baik seperti etos kerja yang tinggi dan disiplin dari bangsa lain yang sudah maju untuk meningkatkan kemajuan bangsa. Sedangkan pengaruh negatif globalisasi terhadap nilai-nilai nasionalisme setidaknya ada lima: pertama, globalisasi mampu meyakinkan masyarakat Indonesia bahwa liberalisme dapat membawa kemajuan dan kemakmuran. Kedua, dari globalisasi aspek ekonomi, hilangnya rasa cinta terhadap produk dalam negeri karena banyaknya produk waralaba luar negeri membanjiri di Indonesia. Ketiga, masyarakat kita khususnya anak muda banyak yang lupa akan identitas diri sebagai bangsa Indonesia karena gaya hidupnya cenderung meniru budaya Barat yang oleh masyarakat dunia dianggap sebagai kiblat. Keempat, mengakibatkan kesenjangan sosial yang tajam antara kaya dan miskin karena persaingan bebas dalam globalisasi ekonomi. Dan kelima, munculnya sikap individualisme yang menimbulkan ketidakpedulian antarperilaku sesama warga. Dengan adanya individualisme maka orang tidak akan peduli dengan kehidupan bangsa. ${ }^{18}$

Tantangan yang dihadapi pendidikan Islam saat ini jauh lebih berat dibandingkan tantangan yang dihadapi pendidikan Islam di masa lalu. Pendidikan Islam dengan pengalamannya yang panjang seharusnya dapat memberikan jawaban yang tepat atas berbagai tantangan tersebut. Untuk menjawab pertanyaan ini, pendidikan Islam membutuhkan sumber daya manusia yang andal,

\footnotetext{
${ }^{18}$ Tri Dimyati, "Pengaruh Globalisasi Terhadap Nilai Nasionalisme", dalam diakses tanggal 9 September 2018.
} 
memiliki komitmen dan etos kerja yang tinggi, manajemenyang berbasis sistem dan infrastruktur yang kuat, sumber dana yang memadai, kemauan politik yang kuat, serta standar yang unggul. Untuk dapat melakukan tugas tersebut, pendidikan Islam membutuhkan unit penelitian dan pengembangan (research and development) yang terus berusaha meningkatkan dan pengembangkan pendidikan Islam. Hanya dengan usaha yang sungguh-sungguh dan berkesinambungan itulah, Pendidikan Islam dapat mengubah tantangan menjadi peluang. ${ }^{19}$

Permasalahan-permasalahan yang dihadapi umat Muslim dunia saat ini tidak lepas dari faktor modernisasi dan globalisasi yang berdampak pada semua aspek kehidupan: ekonomi, sosial, politik, dan juga pendidikan. Pengaruh modernitas mempunyai andil besar dalam mengubah gaya dan pola hidup pada hampir semua lapisan masyarakat. Tidak dapat dipungkiri bahwa anakanak kita belajar sistem nilai kebanyakan dari bidang popular dan media massa. Pengaruh kolonialis yang mengusung paham materialis dan sekulerisme selama berabad-abad telah meninggalkan bekas yang tak bisa

\footnotetext{
${ }^{19}$ Abudin Nata, "Tantangan Pendididkan Islam", dalam http://www.pdfqueen. com, dikases tanggal II September 2018
}

dihapus dalam pola pikir dan sistem nilai di dunia Muslim Indonesia saat ini. Berbagai permasalahan itu juga memperlemah perkembangan karakter generasi Islam. Oleh karena itu, para intelektual Muslim sekarang harus melakukan reorientasi atau rekonstruksi konsep pendidikan. Hal demikian penting karena tanpa hal itu tidak akan pernah mampu membesarkan generasi kita sesuai dengan tuntutan zamannya. Dengan demikian secara singkat dapat disimpulkan: pertama, pemikiranpemikiran Islam yang berkembang selama ini dianggap ketinggalan zaman. Kedua, masih muncul ketakutan di kalangan para pemikir Islam untuk melakukan modernisasi dan reformulasi pemikiran keislaman. Ketiga, meminjam istilah dalam psikologi abnormal umat Islam tampaknya sedang mengidap syndrom of inferiority complex.

Adapun solusi dari masalah masalah di atas: pertama, dengan menambah daya tampung pendidikan. Sejak dicanangkannya Pelita 1 pendidikan mengalami perkembangan, banyak dibangun gedunggedung untuk meningkatkan kualitas. Kedua, untuk meningkatkan kualitas pendidikan adalah dengan memperbanyak pengadaan bukubuku pelajaran, dan alat-alat peraga agar siswa dapat belajar lebih baik. Ketiga, untuk mengatasi 
masalah relevansi maka harus ada kesepakatan antara pihak yang memberikan materi dan masyarakat sebagai sumber pengembangan pendidikan. Untuk mengatasi masalah banyaknya pengangguran maka sekolah memasukkan kurikulum yang dapat menghasilkan tenaga kerja yang menjadi tuntutan masyarakat. Keempat, kurikulum yang senantiasa berubah cenderung mempersulit perkembangan anak apalagi bila disamaratakan antara daerah satu dengan daerah lainnya. Untuk itulah maka perlu dikembangkan kurikulum yang berbasis daerah, namun tetap ada kurikulum nasional yang harus dicapai.

\section{KESIMPULAN}

Sistem pendidikan Islam Indonesia sebagai bagian dari Sistem Pendidikan Nasional, dihadapkan kepada berbagai kenyataan bahwa secara historis kelahirannya merupakan respons yang tumbuh dan berkembang dari aspirasi masyarakat muslim yang mendapat perlakuan diskriminatif dari pemerintah kolonial Belanda. Dalam suasana yang represif system pendidikan Islam Indonesia justru tumbuh dan berkembang dengan subur, bak jamur yang tumbuhdi musim penghujan, yang berfungsi sebagai tempat untukmelakukan perlawanan terhadap hegemoni pemerintahan colonial Belanda.

Selain itu, globalisasi mulai menggeser nilai-nilai pendidikan Islam, tidak jarang orang melupakan pendidikan Islam yang harusnya menjadi

pedoman hidup. Adapun solusi pendidikan Islam dalam menghadapi era globalisasi diantaranya adalah dengan mereformulasi ulang tatanan pendidikan Islam, mulai dari tujuan, visi dan misi pendidikan Islam, metode pembelajaran, manajemen lembaga dan pendidikan Islam, rekrutmen guru dan lain-lain.

Perlunya Reformasi di bidang pendidikan karena adanya berbagai ketidakpuasan dalam penyelenggaraan pendidikan dan hasil-hasilnya. Maka reformasi berupa inovasi-inovasi yang dilakukan itu harus diarahkan pada tujuan untuk meningkatkan kualitas pendidikan secara menyeluruh.

\section{DAFTAR PUSTAKA}

Azra, Azyumardi, 1997. "Pesantren: Kontinuitas dan Perubahan" dalam Nurcholish Madjid, BilikBilik Pesantren: Sebuah Potret Perjalanan, Jakarta: Paramadina, Barnadib, Imam, Filsafat Pendidikan, Yogyakarta: Adicita, 2002. , Dasar-dasar Kependidikan: Memahami Makna dan 
Perspektif Beberapa Pendidikan

(Bogor: Ghalia Indonesia. 1996.

Buchori, Mochtar, 1992, "Posisi dan

Fungsi Pendidikan Agama Islam

dalam

Kurikulum Perguruan Tinggi

Umum," Makalah, pada Seminar

Nasional di IKIP Malang, 24

Februari,

Danim, Sudarwan, 2003. Agenda

Pembaruan Sistem Pendidikan,

Yogyakarta: Pustaka Pelajar,

Delors et al., , 1997. La Educación

Encierra Un Tesoro

Dimyati, Tri, "Pengaruh Globalisasi

Terhadap Nilai Nasionalisme",

dalam

diakses tanggal 9 September

2018.

Drewes, G.W.J, An Early Javanese Code of Muslim Ethics, The Hague:

KITL V Nijhoff Bibliotheca Indonesia, 1978.

Mahfudh, Sahal, 1994. Nuansa Fiqih

Sosial, Yogyakarta: LKiS,

Mastuhu, 2004. Menata Ulang Pemikiran Sistem Pendidikan

Nasional dalam Abad

2l,Yogyakarta: Safria Insani

Press,

Mas'ud, Abdurrahman, 2002. "Sejarah dan Budaya Pesantren" dalam

Dinamika Pesantren dan
Madrasah, (ed.) Ismail SM, et. al., Yogyakarta: Pustaka Pelajar, Musthafa Rembangy, 2008. Pendidikan Transformatif, Yogyakarta: Teras,

Muhaimin, Pengembangan Kurikulum Pendidikan Agama Islam di Sekolah, Madrasah dan Perguruan Tinggi, Jakarta: Rajawali Pers, 2005.

Mochtar, Affandi Membedah Diskursus Pendidikan Islam, Ciputat: Kalimah, 2001.

Nata, Abudin, "Tantangan Pendididkan Islam", dalam http://www.pdfqueen.

com, dikases tanggal 11 September 2018

Sairin, Sjafri, 2002. Perubahan Sosial Masyarakat Indonesia: Prespektif Antropologi, Yogyakarta: Pustaka Pelajar,

Soedijarto, Landasan dan Arah Pendidikan Nasional Kita, Jakarta: Kompas, 2008.

Soyomukti, 2008. Nurani, Pendidikan Berperspektif Globalisasi, Yogyakarta: Ar-Ruzz Media,

Suyanto, 2001. Reformasi Pendidikan Nasional, Jakarta: Komite Reformasi Pendidikan Departemen Pendidikan Nasional, 
